\title{
The Use of SQ3R Method in Improving The Third Grade Student's Learning Motivation and Achievement in English Reading it Department's Student at SMK Ibnusina Batam
}

\author{
Rikhi Maida Lestari ${ }^{1}$, Fahmi Rizal $^{2}$, Hansi Effendi ${ }^{3}$, Basorudin $^{4}$, Indra Wijaya ${ }^{5}$ \\ Master of Technology and Vocational Education Masters Program, Faculty of Engineering, \\ Padang State University, Padang, Indonesia ${ }^{1,2,3}$ \\ University of Pasir Pengaraian, Riau Indonesia ${ }^{4}$ \\ University of Putra Indonesia, Padang Indonesia ${ }^{5}$
}

$\left\{\right.$ rikhimaidalestari@yahoo.com $\left.{ }^{1}\right\}$

\begin{abstract}
The finding from the researcher's observation at SMK Ibnusina Batam was that the student's learning motivation and achievement in English reading comprehension were still at a low level. Based on the researcher's assumption, it was due to ineffective instruction used by the teacher. Therefore, the researcher tried to apply SQ3R method learning to improve student's learning motivation and achievement in English reading comprehension IT's a department. This classroom action research was aimed to enhance student's learning motivation and achievement in English reading comprehension IT's a department. There were two cycles done in this research, and each cycle consisted of four steps; planning, acting, observing, and reflecting. The researcher provided observation sheets, questionnaire, and test for data collecting. Based on the data analysis shown from cycle I to II, student's learning motivation and achievement in English reading comprehension IT's department were improved. The student's motivation was improved from "ENOUGH" with $60.8 \%$ to "GOOD" category with $63 \%$. The students had gained the minimum standard of achievement which was 75 . The average score of the students in reading comprehension in pre-cycle was 69.09 and improved to 80.23 in cycle II. Prior implementing the cycle only 6 of 22 student's or $27.3 \%$ passed and increased to $36.4 \%$ or 8 of 22 students in cycle I. in cycle II, 19 of 22 or $86.4 \%$ students had passed, and the improvement from pre-cycle to cycle II was $59.1 \%$.
\end{abstract}

Keywords: SMK Ibnusina Batam, SQ3R Method, Motivation, Achievement

\section{Introduction}

To develop learning to read understanding of English language lessons[1] it is necessary to have interesting learning models and methods. One method that can be used to improve motivation and reading comprehension ability is to use the SQ3R learning method which stands for survey, question, read, recite, review. Many students are motivated in the learning process, among them are those who sleep, do not want to do the task, and learning outcomes become low. This can be seen from the results of the tests that have been conducted. In 
implementing this SQ3R learning method students are invited and directed to be active in learning activities, with reading activities, making questions, delivering answers using their language. Apart from that, the SQ3R method invites students to be able to understand reading through the stages of reading and recite[2], [3].

In the SQ3R method, the first stage is a survey where the teacher gives time to students to survey the reading that students will do before reading the passage. The second stage is the question stage where students are easier to understand the contents of the reading, so students ask the questions in their minds. The third stage is the read stage where students will be given time to answer the questions that have been asked. The fourth stage is reading where students mention important points using their own words. The last stage is a review, so that students are more aware of the content of the discourse, then reviewing the contents of the discourse is held [4].

The SQ3R method is used to study articles, texts, or passage [5], namely:

1. The survey, in researching or examining all texts.

2. Activities, compile a list of questions related to the text.

3. Read, activities to read text actively to find answers to questions that have been arranged

4. Recite, activities to memorize every answer that has been obtained.

5. Review, activities to re-examine all answers based on questions that have been compiled in the second and third steps.

Based on several opinions above it can be concluded that the SQ3R method has five stages of activities that must be passed, namely reviewing, asking questions, reading, telling and repeating. The use of this method can help students to react critically, creatively and systematically.

Students can become active due to being directly involved in the learning process of English subjects. This can make students interested in learning materials. In addition, it can make students more interested in reading comprehension skills in English and the method is able to improve reading comprehension skills by practicing directly according to the role given.

Using the SQ3R method students can directly enter into communication activities using English that can develop the use of English skills. In accordance with the description above, researchers chose to use the SQ3R method to improve reading skills in understanding English learning activities in the IT field, because this method can be used to create an active and interesting English learning atmosphere.

\section{Method}

This research is a Classroom Action Research which is a research activity with a class context that is implemented to be able to solve learning problems faced by teachers, in improving the quality and learning outcomes and trying new things in the teaching and learning process to improve quality and learning outcomes. According to Hopkins class action research is a study by combining research procedures with substantive action, an action that can be done in the discipline of inquiry, or is a person's attempt to understand what is happening and while involved in the process of improvement and change[6]-[9].

Apart from that, classroom action research is in the form of research (action research) that can be done by teachers in class and has several series of "research-action-research-actionresearch-action ...", The series is done solving the problem [10]. So it can be concluded that classroom action research is a research activity carried out by teachers in the classroom and aims to solve learning problems to improve the results and quality of learning[11]-[13]. 
In this study, the action was taken to apply the Cooperative learning model of the SQ3R Method (Survey, Question, Read, Recite, Review) to increase learning motivation and students' reading comprehension abilities. The researchers targeted the achievement of completeness according to the stipulated by the Ministry of National Education, which amounted to $85 \%$. In its implementation, researchers are assisted by colleagues who act as collaborators and collaboratively carry out observations on the activities of students and teachers in the learning process of reading comprehension at Ibnu Sina Vocational School Batam.

\section{Result and discussion}

\subsection{Learning Outcomes of Reading Text Comprehension in the IT field}

In the cycle I, an evaluation was held by giving a test to students. Student learning outcomes can be seen from the following table:

Table 1. Student Learning Outcomes in Cycle I

\begin{tabular}{|c|c|c|}
\hline Value Range & The number of students & Description \\
\hline $50-59$ & 1 Person & Not finished \\
\hline $60-69$ & 6 Persons & Not finished \\
\hline $70-74$ & 6 Persons & Not finished \\
\hline $75-85$ & 8 Persons & Finished \\
\hline $86-95$ & 1 Person & Finished \\
\hline $95-100$ & 0 & -- \\
\hline Total & 22 Persons \\
\hline \multicolumn{2}{|c|}{ Source: Processed Data of Researchers (2018) }
\end{tabular}

From the student learning outcomes in the cycle I, it was seen that out of 22 students, only nine students completed or $41 \%$, while 13 students or $59 \%$ were not yet complete. The low student learning outcomes are caused by students being less careful in reading the text content in the questions, just answering carelessly and always working in a hurry so that the results obtained are not satisfactory. The low student learning outcomes are also caused because students are not familiar with the learning model applied by the teacher. Individual student learning outcomes can be seen in Appendix 14.

At the end of the cycle before the researcher reflects with collaborators, the researcher gives a questionnaire for students' responses, the results of which are shown in Annex 9. This is to find out how far students respond to the SQ3R learning method which will also be a reference for the next action by the expectations of researchers.

Table 2. Student's responses to the SQ3R Method of Cycle I

\begin{tabular}{|c|c|c|c|}
\hline No & Category & Total & Percentage \\
\hline 1 & Less & 0 & $0 \%$ \\
\hline 2 & Enough & 13 & $59 \%$ \\
\hline 3 & Good & 9 & $41 \%$ \\
\hline \multicolumn{2}{|c|}{ Enough } \\
\hline
\end{tabular}

Source: Processed Data of Researchers (2018) 
From the table above, it shows that student responses to the SQ3R learning method for each element are good, although it is still not very satisfying this is evidenced from 22 students who gave answers, 13 while giving enough responses with a percentage of $59 \%$ while 9 people responded well with the percentage of $41 \%$ of the analysis data can be seen in Appendix 10. For this reason, the researcher will give the questionnaire back to cycle II and look back on whether the student's response to the SQ3R learning method is good enough and makes student learning motivation increase

\subsection{Learning outcomes}

Based on the data obtained from the cycle I, the learning outcomes of English subjects using the SQ3R method for reading comprehension of the English text in the IT field have not yet obtained maximum results. Referring to the Ministry of Education's regulations that the minimum grade completeness that must be achieved in the exam is $85 \%$, while in the cycle I of this study, the new results reach $41 \%$, so it is still very far from the expected and determined results. Then conclusions are taken with student learning outcomes that have not been maximal; the action will be continued to cycle II. To improve learning outcomes, a number of actions will be added in cycle II, including giving additional activities to students, namely home learning activities in the form of assigning worksheets to the material taught to provide a deeper understanding of the material taught, giving material discussion to students, to be studied at home, so that in the next meeting students have better understood and understanding of learning activities.

\section{Conclusion and suggestions}

Referring to the results of the research conducted by applying the SQ3R class XII ITA learning method at the Ibnu Sina Batam Vocational High School in reading the understanding of English texts in the IT field on English subjects, it can be concluded that:

The application of the SQ3R method can increase student learning motivation. This can be seen from active students in the learning process that is discussing, interacting and communicating, cooperating to work on tasks and helping each other in their groups and students have presented the results of their group work.

The application of the SQ3R method can improve student learning outcomes with a marked increase in the number of students who achieve completeness in the two cycles carried out by the established KKM which is 75 . Before applying this SQ3R method in reading comprehension, students who achieved completeness were only six students $(27.3 \%)$. After applying the SQ3R method in the cycle I the number of students who completed there was eight people $(36.4 \%)$. In cycle II after returning to the SQ3R method, students who achieved completeness were 19 students $(86.4 \%)$. With an average value of 72.5 in cycle I, then the cycle II increases by an average value of 80.23 which has exceeded the minimum completeness criteria limit of 75 .

Based on the results of the research that has been done, it can provide input to researchers and other English teachers on the importance of applying the SQ3R method in reading comprehension lessons especially for English lessons which usually represent learning that is less attractive to students and considered difficult.

The findings in this study can meet the expectations of teachers to increase motivation and student learning outcomes, especially in reading comprehension. The application of the SQ3R 
method is expected to provide good progress in reading comprehension, especially in English lessons.

It is expected that the next researcher who will use the SQ3R method can pay attention to the vocabulary used in the news item text. The teacher should analyze the appropriate method given in accordance with the characteristics of student learning styles.

\section{References}

[1] H. R. Gerber and A. Onwuegbuzie, “Why can't we always learn like this?' Gamesbased learning and the English language arts classroom: Lessons learned and practical applications," in 2013 IEEE 63rd Annual Conference International Council for Education Media (ICEM), 2013, vol. 51, pp. 1-1.

[2] Guozhen Zhang, Zixue Cheng, Tongjun Huang, Aiguo He, and A. Koyama, "Design of an effective learning method SQ3R based distance learning system," in First International Symposium on Cyber Worlds, 2002. Proceedings., 2002, pp. 318-322.

[3] Guozhen Zhang, K. Saitou, Zixue Cheng, A. Koyama, A. He, and Tongjun Huang, "Design of SQ3R-based support method for course contents provision in distance learning systems," in Proceedings 21st International Conference on Distributed Computing Systems Workshops, 2001, pp. 326-331.

[4] A. Agustina, "Efektivitas Metode SQ3R (survey, question, read, recite, review) terhadap Kemampuan Reading Comprehension Wacana Bahasa Inggris Siswa Kelas X Semester Genap SMA Negeri 6 Yogyakarta.," E-Jurnal Skripsi Mhs. TP, vol. 4, no. $1,2015$.

[5] A. Bakhtiar, "Improving Students' Reading Comprehension by Using SQ3R Method," Scope J. English Lang. Teach., vol. 2, no. 2, p. 99, Mar. 2018.

[6] W. Wei, X. LiZhen, and D. Yisheng, "Research for Classroom Instruction Ideal and Teaching Method," in 2010 Second International Workshop on Education Technology and Computer Science, 2010, vol. 2, pp. 547-550.

[7] G. Majgaard, "Design-Based Action Research in the World of Robot Technology and Learning," in 2010 Third IEEE International Conference on Digital Game and Intelligent Toy Enhanced Learning, 2010, pp. 85-92.

[8] L. Zeng, M. Zuo, and X. Lu, "Research into Application of Interactive Whiteboard to Interactive Educational Mode," in 2010 International Conference on Computational Intelligence and Software Engineering, 2010, pp. 1-4.

[9] O. Rombot, "The Application of Traditional Games to Develop Social and Gross Motor Skills in 6-7 Year-old Children," in 2017 International Symposium on Educational Technology (ISET), 2017, pp. 116-120.

[10] W. Kusumah and D. Dwitagama, Mengenal Penelitian Tindakan Kelas. Jakarta: PT. Indeks, 2011.

[11] L. Wang and C. Zhao, "Artificial-Society-Based Classroom Behavior Dynamic Research," in 2009 Second International Symposium on Intelligent Information Technology and Security Informatics, 2009, pp. 183-187.

[12] H. Zhao, "A Research on Flipped Classroom-Based Collaborative Knowledge Building Run on Web-Supported Learning Platform," in 2015 International Symposium on Educational Technology (ISET), 2015, pp. 137-140.

[13] K. Rukun, B. H. Hayadi, and M. S. Hartawan, "Design and Analysis of Expert System Based on Information System to Diagnose Computer Failures Using Forward Chaining Method," Int. J. Eng. Technol., vol. 7, no. 3.5, pp. 124-126, 2018. 
